\title{
Ethnicity and child survival in Nigeria'
}

\author{
Fayehun Olufunke ${ }^{2}$ and Omololu Obafemi \\ Department of Sociology, University of Ibadan \\ funke.adesanmi@mail.ui.edu.ng
}

\section{Abstract}

This study examined specific socio-cultural practices, which vary among different ethnic groups, as they affect childhood morbidity and mortality in Nigeria. Data from Nigeria Demographic and Health Survey (NDHS) 2003 were complemented with 40 focus group discussions and 40 in-depth interviews among selected ethnic groups in Nigeria. An examination of the Direct Estimates and Cox regression on childhood mortality indicate significant differences, with ethnic groups in the northern part of Nigeria having the highest risk. The values placed on children among all ethnic groups are reflected in different socio-cultural beliefs and practices with significant influence of maternal education. Although the assumption that specific socio-cultural practices might be salient to exposure of children under five years to childhood mortality was supported in the study, the differences observed are more a reflection of the mother's household environment and socioeconomic variables.

Keywords: Nigeria, childhood mortality, socio-economic, culture, ethnicity

\section{Résumé}

Cette étude a examiné les pratiques socio-culturelles spécifiques, qui varient entre les différents groupes ethniques, car elle affecte la morbidité et la mortalité infantiles au Nigeria. Les données en provenance du Nigeria Demographic and Health Survey (enquête démographique et sanitaire) 2003 ont été complétées avec 40 groupes de discussion et 40 entrevues en profondeur auprès de certains groupes ethniques au Nigeria. Un examen du Budget des dépenses directes et de régression de Cox sur la mortalité infantile montrent des différences significatives, avec des groupes ethniques dans la partie nord du Nigéria ayant le plus de risques. Les valeurs placées sur les enfants dans tous les groupes ethniques se retrouvent dans les différentes croyances socio-culturelles et des pratiques ayant une influence significative de l'éducation maternelle. Bien que, l'hypothèse que les pratiques socio culturelles spécifiques pourraient être saillants de l'exposition des enfants de moins de cinq ans pour la mortalité infantile a été pris en charge dans l'étude, les différences observées sont plus d'une réflexion de l'environnement ménage de la mère et les variables socio-économiques.

I. This article is extracted from Ph.D thesis submitted to the Department of Sociology, University of Ibadan, Nigeria.

2. Corresponding author: Olufunke A. Fayehun, Department of Sociology, University of Ibadan, Nigeria; E-mail: funke.adesanmi@mail.ui.edu.ng 
Keywords: Nigeria, la mortalité infantile, socio-économique, la culture, l'ethnicité

\section{Introduction}

While it is well known that some developing countries are still lagging behind in achieving Millennium Development Goal 4, the 2009 World Health Statistic shows that fourteen out of fifteen countries with the under-five mortality rate above I50 are in Africa. An examination of the under-five mortality rates across Africa also revealed that the West African countries experienced mortality up to two times higher than neighboring countries in Northern and Southern Africa (Rutstein, 2000; Balk et al., 2004). Further comparison across countries in Africa shows that childhood mortality in Nigeria is among the highest.

In the early 1990 to 1998, the under-five mortality in Nigeria was estimated to be 234 deaths per 1000 live births. This dropped to 201 per 100 live births by 2003. Even though, there has been a further decline by 2009 to 178 per 1000 live births as estimated by World Health Statistic 2009, this fell short of the World Summit for Children's national goal of reducing infant mortality rate to $50 / 60$ per 1000 and under-five mortality rates to $70 / 80$ per 1000. For example, Nigeria's figure of I 78 per 1000 live births in 2009 is much lower than the regional average of 145 per 1000 live births. Therefore, childhood morbidity and mortality have attracted the attention of government and non-governmental organizations. This is evidenced by the constant search for adequate measures to enhance child survival. The country has adopted and implemented some major global initiatives affecting children, such as the Safe Motherhood Initiatives, Making Pregnancy Safer, Baby-Friendly Hospital Initiatives (BFHI) and Integrated Management of Childhood IIIness (IMCl). Others are Roll Back Malaria initiative (RBM), elimination of lodine Deficiency Disorders (IDD), Vitamin-A Deficiency control and National Programme on Immunization (Policy Project 2002).

Despite these initiatives and programmes in Nigeria, the under-five mortality rate is still high. A breakdown of causes of under-five mortality and morbidity in Nigeria according to $\mathrm{WHO}$ statistics attributed $20.4 \%$ to malaria; $3 \%$ to HIV/AIDS; $13.5 \%$ to diarrhoea illness; 19.5\% to neonatal deaths; I I\% to measles; $17 \%$ to acute respiratory infection; $2 \%$ to injury and $13.6 \%$ to others not mentioned. Some of these causes are related to maternal social characteristics.

Childcare practices of a mother, which could be traced to her ethnic membership, can affect the way in which children are exposed to the contaminants in the household environment. Ethnicity is an important maternal characteristic that can create differences in child care practices. Maternal beliefs and attitude are dictated by some cultural practices acquired within the family setting. This varies greatly from one society to another because societal norms, values and beliefs, which tend to shape the decisions of individual members, differ within and across communities. Ethnicity is the basis of social organisation in 
the traditional setting. Ethnic groups are identified based on language and similarities in social systems and cultural practices, thus, various attitudes and behavioural practices towards childhood morbidity and mortality (Yinger, 1985; Otite, 1990; Schaefer, Smith and Grekul, 2009). This maternal characteristic has not been adequately researched as an influence on childhood mortality in light of the countless studies that emphasized the central importance of maternal characteristics and behaviour for child survival in Africa (Brockerhoff and Hewett, 1998; Ogunjuyigbe, 2004; Wahab, 2004; Teerawichitchainan and Phillips, 2008).

Studies from different parts of Africa have shown that the risk of childhood mortality differs among ethnic groups (Brokerhoff and Hewett, 2000; Maccassa et al., 2006). It is generally believed that variations in mortality across ethnic groups are due to differences in socio-economic status, accessibility to health care facilities and services and socio-cultural practices. As observed by Gyimah (2002), ethnic differences in infant mortality in Ghana mainly reflect socio-economic disparities among groups rather than intrinsic cultural norms; each ethnic group has its own corpus of knowledge and practices in the sphere of health and child care. Furthermore, in Kenya, Venkatacharya (1991) found a significant association between ethnicity and infant mortality. He observed that children of the Luo group had the highest mortality risks while those of the Kikuyu group had the lowest mortality risks.

In Nigeria, it is pertinent to understand the effect of mother's ethnic group membership on childhood mor- tality as there are some well-known ethnic and cultural practices in Nigeria, which could affect the health of the adherent positively or negatively. For instance, breastfeeding for two years can prolong postpartum amenorrhea; hence encourage adequate spacing of births. This prolonged breastfeeding also encourages birth spacing through sexual abstinence among some ethnic groups because of the belief that sexual activity while breastfeeding could contaminate the breast milk.

However, Ajala (2002) pointed out that there are some other constraints on full implementation of breastfeeding by mothers which have some cultural undertone. He stated that constraint on breastfeeding include strenuous work undertaken by mothers, poor feeding habits of the mother and lack of the male supportive role. Even though older women in most of the ethnic groups cook and provide adequate care for mothers after the delivery for 40 days with the belief that variety of food will restore the lost nutrient during pregnancy, restriction on some certain food for mothers can cause malnutrition to the mother and child. Further, among some groups in Nigeria, traditional breastfeeding weaning practices can be detrimental to the health of children. Weaning is the time when food other than milk is successfully introduced into an infant's diet (Louise Ross, 198I). In Nigeria the usual first weaning food is called pap, akamu, ogi, or koko and is made from maize, millet or guinea corn, which is low in protein content. Children are thereafter introduced to adult solid food, which may be too heavy to take the needed quantity. This has been a major cause of malnu- 
trition, which increases susceptibility to infectious diseases and affects child mortality from diseases such as diarrhoea, whooping cough, and acute respiratory infection (Onofiok and Nnanyelugo, 1988).

Early marriages among ethnic groups in the northern part of the country have not been healthy for the young women involved. Incidences of vesicovaginal fistula (VVF) are prevalent in such situations. Likewise, adherence to circumcision rite of passage otherwise known as Female Genital Mutilation has resulted in several medical complications and higher risk of HIV infection for some young women. Further, the belief that infant should be purged after delivery to rid them of impurities swallowed in the uterus is another dangerous practice among some ethnic groups in Nigeria (Alabi, 1990; Oyekanmi, 1998; Onyeabochukwu, 2007). In Nigeria, there are diverse ethnic groups with the peculiarculture and housing environment, consequently various adaptive mechanisms on childhood morbidity and mortality.

As Gaisie (1990) asserts on African cultures, ethnic frameworks are the most important determinants of adaptation to modern conditions, including changes in health behaviour. It hasbeen observed that data on childhood mortality in Nigeria are scarce because of poor record systems; the recent available data that capture the whole country are from the 2003 Nigeria Demographic and Health Survey (NDHS). The NDHS though asked questions on the ethnic origin of mothers; the summary report did not show the ethnic differences on childhood mortality in Nigeria. There are imprecise accounts of childhood mortality among ethnic groups and a systematic examination of ethnicity as it affects child survival chances across Nigeria has not been made to date. This study will therefore, provide detailed ethnic differential on childhood mortality in Nigeria using the NDHS 2003 data. This information on childhood mortality would also serve the needs of the health ministry by identifying sectors of the population that are at high risk (NPC, 2004).

\section{Theoretical framework: ecological system theory}

The ecological system theory proposed by Bronfenbrenner focuses on the quality and context of child's environment (Bronfenbrenner, 1979). The theory examines the child's development within the system of relationships in his or her environment. A child must survive some stages in life in order to develop and thus, child survival is embedded in child development. This ecological system theory answers the question of how a child's surrounding hinders or helped the survival of a child (Bronfenbrenner, 1979).

Therefore, to study a child's development cum survival, the child and her immediate environment as well as the interaction of the larger environment, which brings in the issue of social environment, must be examined. Microsystem, mesosystem, exosystem and macrosystem were the terms used in explaining this theory. The layer closest to the child is the microsystem, it reflects the outcome of the relationships and interactions a child has with her immediate surroundings (Berk, 2000). Structure that influences the outcome at this level includes family, school, neighbourhood, 
or childcare environments.

The mesosystem layer shows the interaction between structures of the child's immediate environment as it relates to the microsystem; interactions at this level can impact the inner structures. In this study, the mesosystem will be the household environment of a child, which has an influence on the child's health outcome, thus the child's survival. At this level, the influence from the household environment has a great impact on child's morbidity, mortality, survival and development. The exosystem layer defines the larger social system in which the child does not function directly. The structures in this layer impact the child's survival hence the development by interacting with some structure in her microsystem (Berk, 2000). Although, a child may not be directly involved at the exosystem level, the negative or positive force which involves interaction within his/ her system is felt. Factors such as socioeconomic, maternal and demographic are at this level.

The macrosystem layer is considered the outermost layer in the child's environment; it comprises cultural values, customs, and laws (Berk, 2000). The effects of the macrosystem have influence throughout the interactions of all other layers. For example, if it is the belief of the culture that women should marry early, hence begin childbearing early; the culture is indirectly affecting the survival of such a child. This brings in the ethnic group of a parent; it has an overall effect on the survival of a child (Bronfenbrenner, 1979).

\section{Data and methods}

Nigeria is a West African country situated at the eastern coast of the Gulf of Guinea and north of the equator. Nigeria, the fourth largest country in Africa, covers an area of 923,768 square kilometers and is made up of 36 states and a Federal capital territory (FCT) comprising 774 Local Government Areas (LGAs). These states are grouped into six geopolitical regions: North-Central, North-East, NorthWest, South-East, South-South and South-West. According to the Population Reference Bureau (PRB) estimate of 2008, the population of Nigeria is about 148 million with the annual growth rate of $2.5 \%$. Nigeria has the largest population of any African country at about 160 people per square kilometer making it the most densely populated country in Africa. The Nigerian population is very young with about $45 \%$ of its people under age fifteen (PRB, 2008).

There are many social groups within the boundary of Nigeria with distinct cultural traits, which are reflected in the diverse behaviour of the people with over three hundred ethnic groups. Figure I shows a map of Nigeria by distribution and location of major language ethnic groupings for this study. There is overlapping in the distribution because of the clustering of some ethnic groups in some states. For instance, ethnic groups in Borno State include Kanuri, Hausa-Fulani, Babur, Shuwa and Marghi. Also, Zamfara State being predominantly Hausa-Fulani group has Nupe, Tiv, Kanuri and Gwami Kamuku, Kambari, Dukawa, Bussawa and Zabarma dominant in the state. 


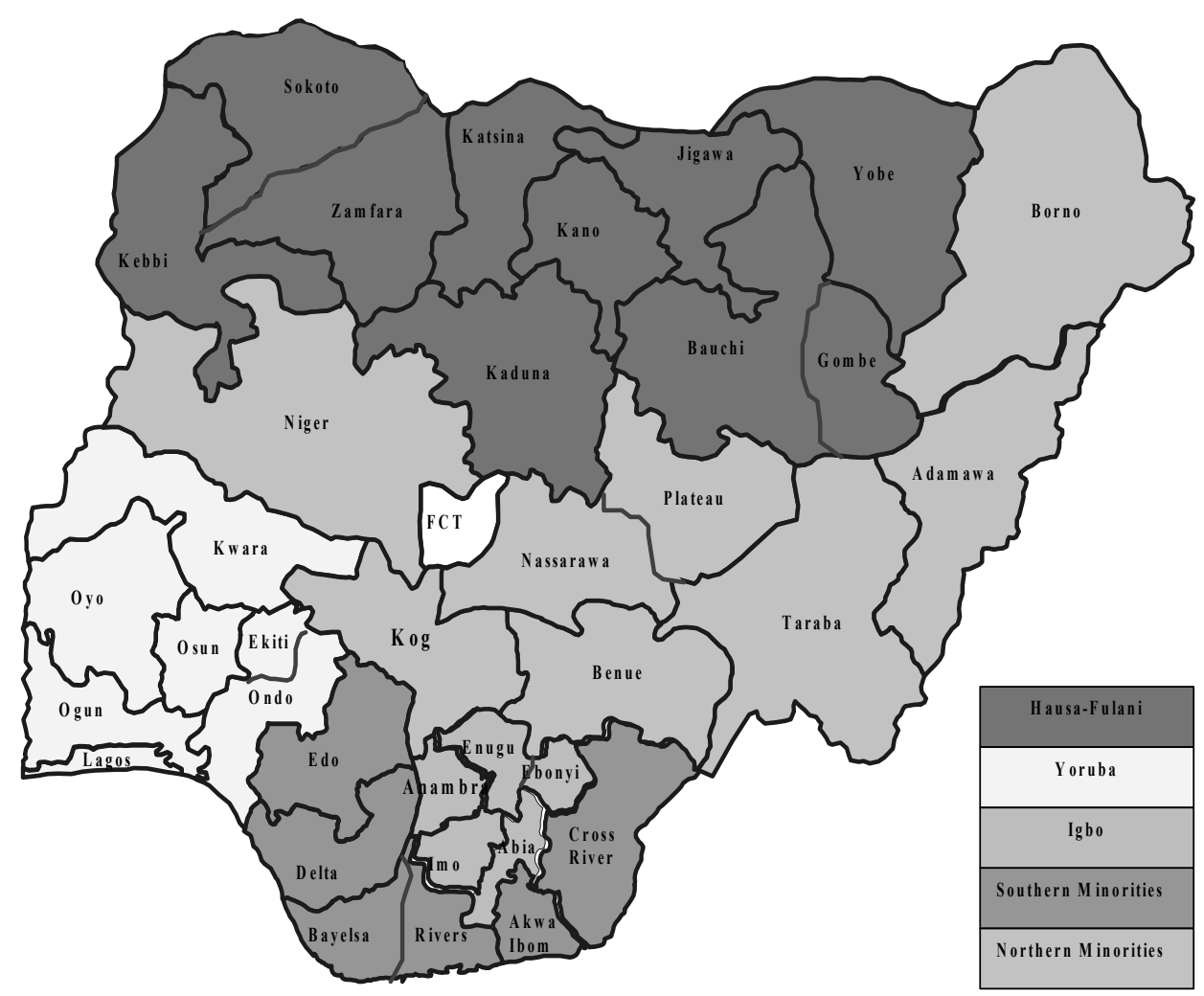

Figure I A map of Nigeria showing the distribution and location of major language ethnic groupings for this study.

This study involves the integration of qualitative method and secondary data. The survey based secondary data was complemented with focus group discussion (FGD) and in-depth interview (IDI) methods. Population-based quantitative data obtained from Nigeria Demographic and Health Survey 2003 (NDHS 2003) was utilized to answer the stated research questions for this study. The third in a series under the worldwide Demographic and Health Surveys Programme, NDHS 2003 is a nationally representative, stratified, self-weighting probability sample of women in the reproductive ages of 15 to 49 years. It has a wider scope and geo-referenced, making the findings to be more comprehensive than the two previous surveys (1990 and 1999) in Nigeria. The structured interview method adopted in the NDHS 2003 used standardized individual and household questionnaires that facilitate crosscountry comparison.

For the quantitative data, this study extracted information on maternal and child health that covers the whole 
country from the children file of NDHS 2003. In order to correct for over sampling and under sampling, the sampling weights of mothers were applied for the data analysis. Ethnic membership of mothers was broadly categorised into Hausa-Fulani, Igbo, Yoruba, Southern and Northern minorities' ethnic groups. The Hausa-Fulani, Igbo and Yoruba are the three largest and dominant ethnic groups in the Nigeria. The other ethnic groups fall under the broadest groupings of the linked ethnic units by region and geo-political zoning of the country: Northern and Southern minorities (Otite, 1990; NPC, 2004).

\section{Qualitative sampling procedure}

This study developed a suitable sampling framework for qualitative data based on variables that are pertinent to this study. Some states and locations were selected purposively for the focus group discussions and in-depth interviews. The sampling selection strategy was based on ethnic membership, location, age and educational status of mothers. The first stage was to purposively select one out of the states in the country where the ethnic groups clustered. Second, major towns were selected within each state. Third, focus group participants and IDI respondents for the study cut across rural, urban, educated and non-educated in the selected locations.

Hausa-Fulani people in the northern part of the Nigeria are found in Kebbi, Sokoto, Zamfara, Katsina, Kaduna, Kano, Jigawa, Bauchi, Yobe and Gombe. However, Zaria, a major city in Kaduna state, was purposively selected for the qualitative data collection. Zaria is also known as the capital of Hausa kingdom. Bomo district was selected for rural area while Kofan Gayan was selected for urban area. The lgbo are spread over five states in Nigeria namely: Enugu, Ebonyi, Imo, Anambra and Abia states. For this study, lgbo mothers interviewed were purposively selected from Awka town in Anambra State in order to understand the ethnic perception to child care and mortality because of its traditional lgbo setting. Awka South Local Government Area was purposively selected because of indigeneous lgbo setting in the town.

The Yoruba are clustered in Lagos, Oyo, Ondo, Ogun, Osun and Kwara States while major Yoruba cities are Lagos, Ibadan, Abeokuta, Akure, llorin, ljebu Ode, ljebu-lgbo, Ogbomoso, Ondo, Ota,Ado-Ekiti, Shagamu, Ikenne, Iseyin, Osogbo, llesha, Oyo, llé-Ifè. For this study, Akure was purposively selected for the qualitative data collection of the Yoruba perceptions on childcare, morbidity and mortality because of its traditional nature. Akure, the largest city in Ondo State is in the southwestern region of Nigeria. Although, there has been the influence of modernization on the city, it is still a traditional Yoruba city. ljaw ethnic group, the most populous indigenous inhabitants of the Niger Delta, was selected among the southern minorities ethnic group. This ethnic group is scattered across six states in Nigeria: Ondo, Edo, Delta, Bayelsa, Rivers and Akwa Ibom.. Sagbama, one of the towns in Bayelsa State, was purposively selected for this qualitative study. Sagbama town is located in the heart of Sagbama local government. The selection of Sagbama is because of the clustering and high population of ljaws in the town.

The other minorities' ethnic group 
in the northern region of Nigeria selected for this study is the Tiv. The Tiv are located in the northern provinces of Nigeria, with the majority of them living in the Tiv Division of Benue Province. Benue, a state in the northern minorities' ethnic group region was purposively selected because 14 out of the 23 LGAs in the state belong to the territory of Tiv people. Gboko, a town in the Benue State of Nigeria was further selected for this study. It is the capital of the Tiv tribe and has the official residence of the Tor-Tiv, the paramount traditional ruler of the Tiv people. The above mentioned locations were thus selected in order to understand different ethnic perceptions towards childhood morbidity and mortality.

\section{Variable measurements}

Variables for the household environmental factor includes source of drinking water, time to water source, type of toilet facility, sharing of toilet facility, type of main flooring materials of the household, type of cooking fuel and use of mosquito net for children under five years. Source of drinking water is categorised into piped water, open well, covered well/borehole and surface water (streams, rivers). Time to water source is categorised into on premises, less than 15 minutes and above 15 minutes. Toilet facilities are grouped into the flush toilet, pit toilet and no facility while the toilet is either shared or not. Finished and natural/rudimentary are the categories of flooring materials. Finished materials comprised parquet, polished wood, vinyl/ asphalt strips, ceramic tiles, cement and carpet while natural/rudimentary flooring includes wood plank, bamboo, earth, sand and dung. Type of cooking fuel is catego- rised into Electricity/LPG/Natural gas, Kerosene and Firewood/Charcoal/ Straw. The use of mosquito nets for children under five in the household is grouped into yes or no. Responses for place for hand washing are nowhere, in-dwelling yard/plot or somewhere else.

Demographic variables in this study are maternal age at birth, birth interval, sex of child, type of birth and birth order. Maternal age at birth is grouped into the conventional categories of fertility age of women as follows 15-19, 20-24, 25-29, 30-34, 35-39, 40-44, 4549 years. Sex of child is either male or female while the type of birth could be single birth or multiple births as in the case of twins. Interval between births is grouped by months into, below 24, 2436 and above 36 months while the birth order is from first born to fourth-born and above. The socio-economic factor is measured with variables such as maternal highest educational level, paternal highest educational level, residence, employment status of mothers and wealth index of the family. Maternal and paternal highest educational levels are grouped into No education, Primary, Secondary and Higher education while the residence is categorised into rural and urban. Employment status of mothers is categorised into working and not working. The wealth index, based on assets information and household ownership of consumer item, as categorised in the 2003 NDHS is used with a little modification in the category; lowest and second are regrouped into low, middle, and fourth and highest are regrouped into high.

Cox regression model is used to show the differences in childhood mor- 
tality among Nigerian ethnic groups and the effects of demographic, socio-economic factors and household environment on childhood mortality among Nigerian ethnic. Cox regression model is a survival regression analysis widely deployed in demographic studies of childhood mortality since they obviate the need to exclude recent births given censorship of experience by survey time (Siyan 2000). For this study, the status variable is the dependent variable; if a child is alive ( 0 ) or dead (I). The time variable measures the duration of a child's death in months while the Hazard is the event of death occurring before the child's fifth birthday. The relative hazard shows the extent to which specific attributes predispose children to differential risk of death. A ratio significantly greater than one suggests that children with this attributes have a higher risk of death than the reference category while the relative risk ratio less than one implies that children with this attribute are expected to have lower risk of death than those in the reference category.

\section{Results}

Childhood morbidity among

Nigerian ethnic groups

The pattern of childhood morbidity which could lead to childhood mortality was examined among the ethnic groups. Three major childhood morbidity that were experienced in the two weeks preceding the survey were examined: diarrhoea, fever and cough/ short breath. Dehydration from diarrhea has been identified as major cause of death among young children in Nigeria. Responses as shown in Figure I on diarrhea incidence in the last two weeks preceding the survey revealed that children born to Yoruba women have the least episode of diarrhea. The incidence is higher among the HausaFulani, Northern and Southern minorities' ethnic group. Contributing to this incidence is the source of drinking water for these two ethnic groups as literature has shown that the type of drinking water is a major determinant to diarrhea. This study shows that the ethnic groups with best source of drinking water have the least incidence of childhood diarrhea. Acute respiratory infection characterised by coughing or short rapid breath has been found to be one of the major causes of childhood mortality in developing countries. The Figure 2 also shows the incidence of cough or short rapid breathe among children under-five among Nigerian ethnic groups.

Incidence of cough or short rapid breathes within two weeks preceding the survey is highest among SM group and lowest among the Yoruba. Although, acute respiratory infection is expected to be significant among the ethnic groups where biomass fuel (firewood, charcoal, straw) is used for cooking, it is surprising that the incidence is high among all ethnic groups irrespective of their type of cooking fuel.

Fever is assumed to be common childhood morbidity in developing countries, especially Sub-Saharan Africa (SSA); the findings as shown in Figure 2 did not deviate from this assumption. It is quite alarming that within two weeks preceding the survey, about 39 out of 100 children under-five among HausaFulani, about 32 out of 100 among the Northern minorities, 31 out of 100 among the Southern minorities children under-five reported incidence of fever. 


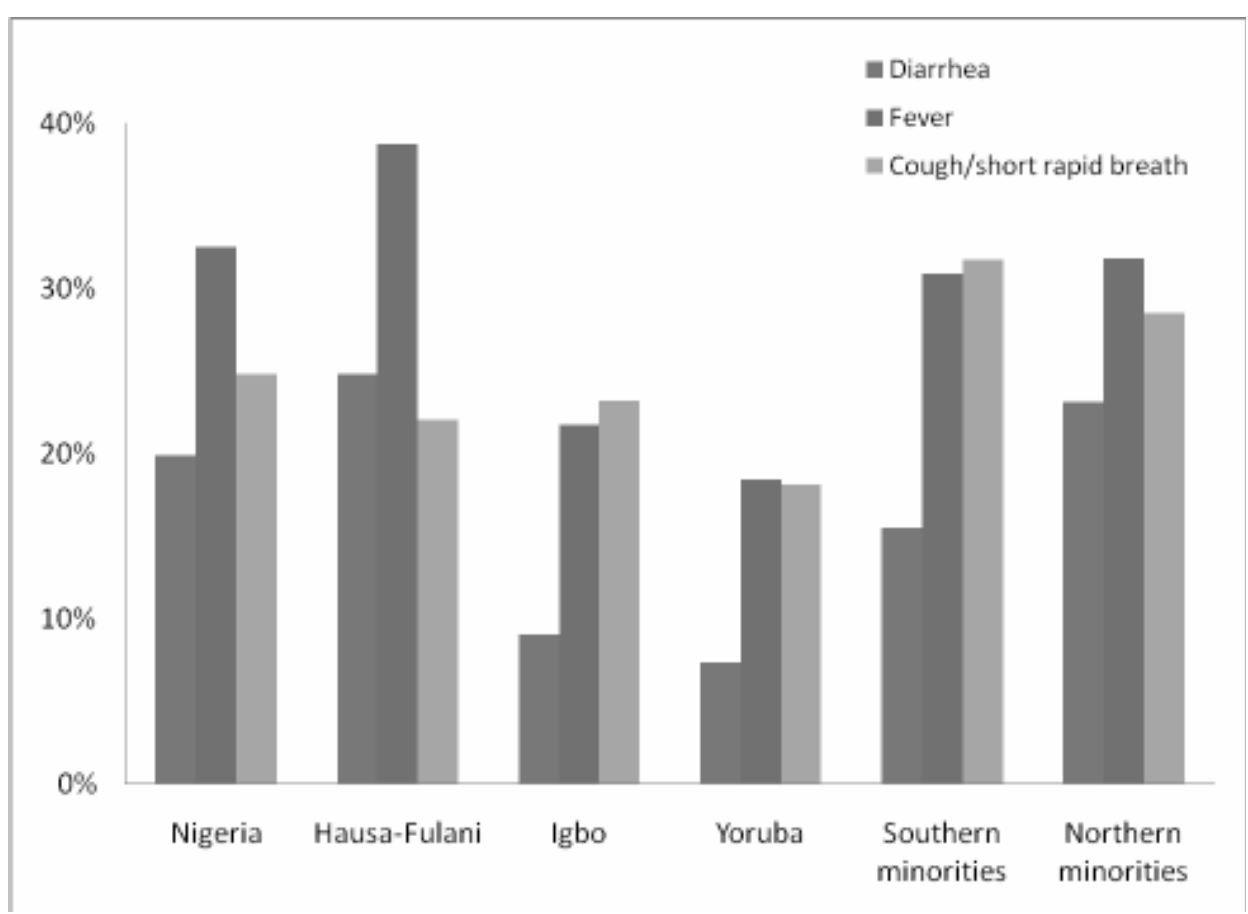

Source: NDHS 2003 Secondary data analysis

Figure 2 Incidence of selected childhood morbidities among Nigerian ethnic group

\section{Ethnic groups perception of childhood morbidity and mortality in Nigeria}

The value placed on a child is a cultural phenomenon which varies from one society to another, that is, from one ethnic group to another. The findings from the qualitative study show that all the mothers linked childhood morbidity to mortality. It is generally believed that with the exception of some children, the cause of death is from illness.

Although, tradition demands that both mother and child should be catered for during pre-natal and postnatal period, it is believed that illness is inevitable among children, especially those less than five years of age. Table I is a summary of findings in the FGDs and IDls among the selected ethnic groups on some childhood morbidity. Further, breakdown of perceived causes of childhood morbidity and mortality according to ethnic membership of mothers are shown in Boxes I to 5 . There are different perceptions on causes of childhood morbidity among Nigerian ethnic groups. Contaminated/ dirty water and teething are generally perceived in all the ethnic groups as causes of diarrhea for children underfive. 
Table I Perceived causes of childhood morbidity among Nigerian ethnic groups

\begin{tabular}{|c|c|c|c|c|c|}
\hline $\begin{array}{l}\text { Childhood } \\
\text { morbidity }\end{array}$ & Hausa-Fulani & Igbo & Yoruba & $\begin{array}{l}\text { ljaw- } \\
\text { Southern } \\
\text { minorities }\end{array}$ & $\begin{array}{l}\text { Tiv- } \\
\text { Northern } \\
\text { minorities }\end{array}$ \\
\hline Diarrhoea & $\begin{array}{l}\text { Teething, un- } \\
\text { treated wa- } \\
\text { ter, unripe } \\
\text { fruit or } \\
\text { change of wa- } \\
\text { ter. Yam moi- } \\
\text { moi, okro } \\
\text { soup, keep- } \\
\text { ing sponge } \\
\text { near well }\end{array}$ & $\begin{array}{l}\text { Improper } \\
\text { care of the } \\
\text { feeding bot- } \\
\text { tle, open } \\
\text { food, not } \\
\text { washing } \\
\text { hands be- } \\
\text { fore eating, } \\
\text { picking dirty } \\
\text { things on the } \\
\text { floor }\end{array}$ & $\begin{array}{l}\text { Untreated/ } \\
\text { contaminated } \\
\text { water, junk, } \\
\text { sugary food, } \\
\text { improper care } \\
\text { of the feeding } \\
\text { bottle, eating } \\
\text { of contaminat- } \\
\text { ed food }\end{array}$ & $\begin{array}{l}\text { Contami- } \\
\text { nated wa- } \\
\text { ter; } \\
\text { contami- } \\
\text { nated food }\end{array}$ & $\begin{array}{l}\text { Untreated } \\
\text { water or un- } \\
\text { cooked food; } \\
\text { teething; } \\
\text { mango; unti- } \\
\text { dy toilet facil- } \\
\text { ity }\end{array}$ \\
\hline Measles & $\begin{array}{l}\text { Hot season, } \\
\text { from God, } \\
\text { evil jinns } \\
\text { (spirit), over- } \\
\text { crowding }\end{array}$ & Heat & $\begin{array}{l}\text { Too much } \\
\text { heat, dry sea- } \\
\text { son }\end{array}$ & $\begin{array}{l}\text { Viral infec- } \\
\text { tion, over- } \\
\text { crowding, } \\
\text { heat }\end{array}$ & $\begin{array}{l}\text { Measles is } \\
\text { seen as nor- } \\
\text { mal }\end{array}$ \\
\hline $\begin{array}{l}\text { Cough / } \\
\text { short } \\
\text { breath }\end{array}$ & $\begin{array}{l}\text { Exposure to } \\
\text { cold, playing } \\
\text { with water }\end{array}$ & $\begin{array}{l}\text { Exposure to } \\
\text { smoke from } \\
\text { firewood or } \\
\text { lemon grass. } \\
\text { Taboo on } \\
\text { wearing } \\
\text { cloth during } \\
\text { "Ozu" festi- } \\
\text { val can ex- } \\
\text { pose } \\
\text { children to } \\
\text { cold }\end{array}$ & $\begin{array}{l}\text { Smoke from } \\
\text { firewood, ex- } \\
\text { posure to bare } \\
\text { floor, improp- } \\
\text { er care during } \\
\text { rainy season }\end{array}$ & $\begin{array}{l}\text { Exposure } \\
\text { to cold; } \\
\text { sleeping on } \\
\text { bare floor; } \\
\text { smoke } \\
\text { from fire- } \\
\text { wood }\end{array}$ & $\begin{array}{l}\text { Exposure to } \\
\text { cold }\end{array}$ \\
\hline Fever & $\begin{array}{l}\text { Mosquito es- } \\
\text { pecially dur- } \\
\text { ing rainy } \\
\text { season }\end{array}$ & $\begin{array}{l}\text { Convulsion } \\
\text { resulting } \\
\text { frommalaria } \\
\text { is seen as } \\
\text { attack from } \\
\text { evil spirit }\end{array}$ & $\begin{array}{l}\text { Mosquito bite, } \\
\text { improper care } \\
\text { of feeding bot- } \\
\text { tle }\end{array}$ & $\begin{array}{l}\text { Dirty wa- } \\
\text { ter; mos- } \\
\text { quito bite, } \\
\text { child play- } \\
\text { ing in the } \\
\text { sun }\end{array}$ & $\begin{array}{l}\text { Contaminat- } \\
\text { ed water, } \\
\text { mosquito } \\
\text { bite }\end{array}$ \\
\hline
\end{tabular}

Source: Fieldwork 2006

The Igbo and Yoruba mothers mentioned improper care of the feeding bottle as cause of childhood diarrhoea. Measles is seen as normal for Tiv children, therefore no precise cause was mentioned, while the remaining ethnic group attributed incidence of measles to heat. Exposure to cold, smoke from firewood and bare floor were men- tioned as causes of cough and catarrh among the children under-five in Nigeria. Even though the pattern of perceived causes of childhood morbidity varied slightly, a higher proportion of mothers, irrespective of residence, mentioned modern treatment/curative measures in all the ethnic groups for this study. For instance, the majority of 
the respondents in all the ethnic groups mentioned the use of oral rehydration therapy for home treatment of diarrhea (though called different names). The lgbo mother further mentioned Saint leaf/ Ugulu as a cure for diarrhea. However, diarrhea will not to be taken to the hospital except in extreme cases of dehydration among the mothers in the rural area. While there was no specified treatment mentioned for measles apart from traditional healer, health centres or hospitals for Hausa-Fulani, Tiv, Igbo and Yoruba, ljaw mothers apply onions, cold water and squeezed sugar water. The ljaw mothers also used long black bitter spice as a cure for cold and catarrh, which they claimed is effective.

In all the ethnic groups studied on childhood morbidity and mortality, some children are believed, will die irrespective of treatment given when they are sick. This happens if the parents' refuse to acknowledge a particular taboo or beliefs that the community value and adhere to concerning children. Among the Hausa-Fulani, common causes of childhood mortality reported include jaundice, vomiting, abdominal discomfort and diarrhea. This implies that mortality usually stems from congenital and hygiene factors.

One of the discussants experienced childhood mortality as a result of pneumonia among the Igbo. Childhood mortality was also attributed to Ogbanje a spirit believed to cause the serious morbidity condition such as convulsion that leads to childhood mortality. The Yoruba like the lgbo believes that some children are possessed by Abiku, an evil spirit believed to be causing recurring deaths of a particular child. The breaking of a taboo by bringing a plantain bunch to the town from the farm is also perceived to cause childhood mortality among the Yoruba.

The common cause of childhood mortality experienced and mentioned by the ljaw mothers is convulsions. Furthermore, there is a belief in the spirit that affects re-incarnation, which made mothers to call such children names like "Timipade" meaning "don't go back" or "Ebafua" which means "You won't die again". This is to forestall the recurrence of the child's death. The killing of children identified as "bad or evil" by native doctors is a socio-cultural factor that affects childhood mortality among the Tiv. Their belief is "Swende"- death that arises when a pregnant woman beholds or touches a dead dog. It is observed that the perceived causes of childhood mortality among these different ethnic groups are affected by their belief systems. A common theme is the belief that an evil spirit induces childhood mortality irrespective of ethnic groups.

An examination of the direct estimates for under-five mortality for all ethnic groups in the study indicates the difference as shown in Figure 3. The theoretical assumption that the modernizing effect of formal education among some ethnic groups can affect the risk to childhood mortality is supported in this study. Hausa-Fulani group has the highest number of deaths of children under-five among the ethnic groups in the country. From the direct estimates of under-five mortality for five years preceding the survey, there are about 156 and 148 deaths per 1000 live births among the Hausa-Fulani and Northern minorities respectively. Conversely, 73 deaths were observed out of 
1000 live births among the Yoruba and Igbo.

Further analysis with Cox regression reveals disparities in childhood mortality among Nigerian ethnic groups. The dependent variable is the event of the death of a child. For this study, it is hypothesized that there is a significant effect of mother's ethnic membership on childhood mortality in Nigeria. For interpretation of the Cox regression results, a risk ratio significantly greater than one indicated that children with this attributes have a higher chance of death than the reference category while the relative risk ratio less than one indicated that children with this attribute are expected to have lower risk of death than those in the reference category. The result is shown in Table 2.

The Hausa-Fulani ethnic group is the reference category because it is the ethnic group with the highest incidence of childhood morbidity earlier examined. The result shows that the ethnicity variable on childhood mortality is significant $(p<0.05)$ particularly among the Yoruba, Igbo and Southern minorities ethnic groups with reference to Hausa-Fulani. The relative hazard of death is significantly lower among children born to Yoruba mothers (0.567), Southern minorities (0.597) and lgbo $(0.630)$ for under-five mortality.

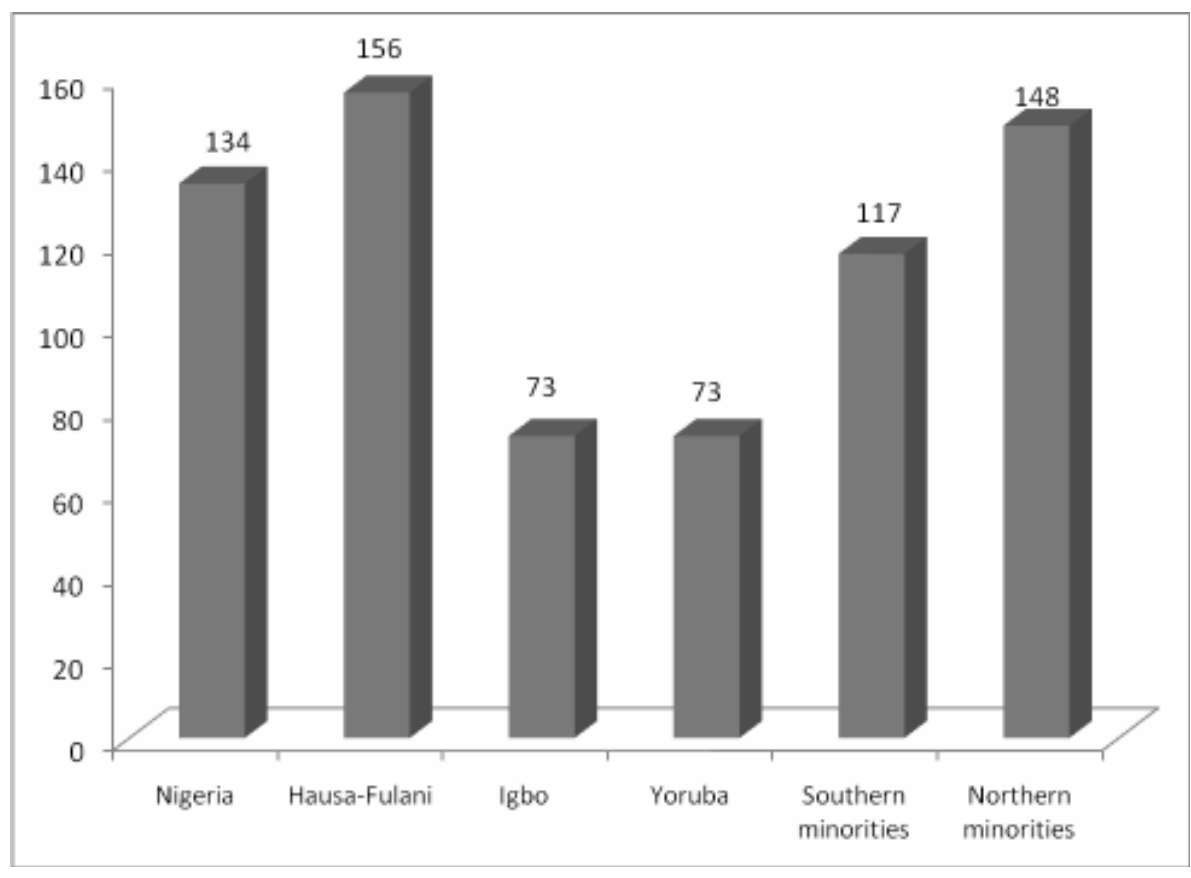

Source: NDHS 2003 Secondary data analysis

Figure 3 Direct estimate of under-five mortality among Nigerian ethnic groups 
Table 2 Cox Regression Analysis on childhood mortality and mothers' ethnic group membership

\begin{tabular}{l|l|l|l}
\hline Variables & $\begin{array}{l}\text { Childhood } \\
\text { mortality }\end{array}$ & $\begin{array}{l}\text { Infant mortality } \\
(0-12 \mathrm{mths})\end{array}$ & $\begin{array}{l}\text { Child mortality } \\
(13-59 \mathrm{mths})\end{array}$ \\
\hline Ethnic groups & & & 1.000 \\
Hausa-Fulani (ref.) & 1.000 & 0.848 & 1.000 \\
Igbo & $0.630^{*}$ & $0.529 *$ & $0.17 I^{*}$ \\
Yoruba & $0.527^{*}$ & 0.789 & $0.387^{*}$ \\
Southern-minorities & $0.597^{*}$ & 0.954 & $0.584^{*}$ \\
Northern-minorities & 0.867 & $0.606^{*}$ \\
\hline
\end{tabular}

Source: Raw data from NDHS 2003*- $p<0.05$

The observed wide disparity between the Yoruba, Igbo, SM ethnic groups and the reference category (Hausa-Fulani) confirms NDHS 2003 findings on regional differences between mothers in the southern part and those in the northern part of the country. The NDHS report was based on the region, whereas the present study is based on actual ethnic group membership in the region. As expected, the NM group did not show any significant difference from the reference category; their relative hazard is closer to the Hausa-Fulani than other ethnic groups. This may be attributable to geographic location and cultural similarity with the reference category. Cox regression analysis of infant and child mortality shows differences among Nigerian ethnic groups. Infants generally have lower chances of survival than those of age I and above; once a child survives the first 12 months, the likelihood of living up to $59^{\text {th }}$ month increases. This is because of children's critical physiological developmental stage before age 12 months. Children born to mothers in the HausaFulani have relative high hazards to infant mortality compared to other eth- nic groups. However, there is a wide margin when all other ethnic groups are compared with the Yoruba on infant mortality. The findings further show that ethnic differential is significant for children aged 13 to 59 months. Those children within the age 13 to 59 months in the ethnic groups in the Southern part of Nigeria can, on the average, survive child mortality than those in the Northern part.

Overall, deaths among Yoruba children are lower than all other ethnic groups surveyed in Nigeria, both infant mortality and under-five mortality. Although, Yoruba, lgbo and SM are from the southern part of Nigeria, presumably an enlightened part because of early impact of western civilisation, more Yoruba infants survive infancy than Igbo and SM ethnic groups. Furthermore, ethnic groups in the Northern region have less access to the artifacts of modernity than those in the Southern region. Less modernized groups tend to have lower chances of child survival that is a higher risk of childhood mortality as observed in this study. 


\section{Factors affecting childhood mortality among Nigerian ethnic groups}

The Cox Hazard regression model technique is used to examine the factors affecting ethnic differentials in childhood mortality in Nigeria. The dependent variable is the event of death of a child. For this study, it is hypothesized that there is an effect of socio-economic, demographic factors and household environment on childhood mortality among Nigerian ethnic groups. Thus, various models are included in the analysis as shown in Table 3.

The first model examines the ethnic groups and childhood mortality. This is the baseline model, referred to as the control variable. The result is as observed earlier in the previous section. The relative hazard of death is significantly lower among children born to Yoruba mothers (0.567), SM (0.597) and lgbo (0.630). The NMs group did not show any significant difference from the reference category. The second model includes the first model and household environmental variables. This is aimed at explaining the pattern and variation of childhood mortality among Nigerian ethnic groups in the presence of household environmental variables. The findings reveal no significant difference in childhood mortality among the ethnic groups when the household environmental variable was introduced into the model. This result is significant for this study as it implied that the disparities in childhood mortality among Nigerian ethnic could be controlled if the household environment is hygienic and improved.

However, among the household environmental variables considered for this study, children who live in houses with covered well/borehole, use the flush toilet and have finished flooring have lower hazard to mortality than others. Although the risk of death of those households that drink piped water is not statistically significant, it is still lower than surface water. In model 3 , where demographic variables are controlled for, the disparities in the risk to childhood mortality among the Yoruba, Igbo and NM ethnic group when compared to the reference category are not statistically significant, though there are decreased in the differences.

For the SM ethnic group, there is significant difference in risk to childhood mortality when compared to reference category with the addition of demographic variables. Children born five years preceding the 2003 NDHS to SM ethnic group mothers have significant lower risk to death than those born to Hausa-Fulani mothers. The household environmental variables on child's death also gave slightly different patterns when demographic variables are controlled for. Children who live in household with open well water, getting water on premises, used flush toilet and finished flooring have lower risk to childhood mortality than others. The findings in this study also reveal a highly significant difference on childhood mortality because of the type of birth; the risk to childhood mortality is significantly lower (0.247) among births that are single when compared to multiple births. 
Table 3 Relative hazards of childhood mortality among Nigerian ethnic groups

\begin{tabular}{|c|c|c|c|c|}
\hline Variables & Model I & Model 2 & Model 3 & Model 4 \\
\hline $\begin{array}{l}\text { Ethnic groups } \\
\text { Hausa-fulani (ref.) } \\
\text { Igbo } \\
\text { Yoruba } \\
\text { Southern-minority } \\
\text { Northern-minority }\end{array}$ & $\begin{array}{l}1.000 \\
0.630^{*} \\
0.527^{*} \\
0.597^{*} \\
0.867\end{array}$ & $\begin{array}{l}1.000 \\
0.755 \\
0.801 \\
0.664 \\
0.936\end{array}$ & $\begin{array}{l}1.000 \\
0.896 \\
0.840 \\
0.639 * \\
0.959\end{array}$ & $\begin{array}{l}1.000 \\
0.909 \\
0.762 \\
0.662 \\
0.979\end{array}$ \\
\hline $\begin{array}{l}\text { Source of drinking water } \\
\text { Piped water } \\
\text { Open well } \\
\text { Covered well/borehole } \\
\text { Surface water (ref.) }\end{array}$ & & $\begin{array}{l}0.815 \\
0.65 I^{*} \\
0.675^{*} \\
1.000\end{array}$ & $\begin{array}{l}0.865 \\
0.68 I^{*} \\
0.708 \\
1.000\end{array}$ & $\begin{array}{l}0.989 \\
0.694^{*} \\
0.805 \\
1.000\end{array}$ \\
\hline $\begin{array}{l}\text { Time to get to water sour } \\
\text { On premises } \\
\text { Less than } 15 \text { mins } \\
\text { Above } 15 \text { mins (ref.) }\end{array}$ & & $\begin{array}{l}0.507 \\
0.868 \\
1.000\end{array}$ & $\begin{array}{l}0.44 I^{*} \\
0.930 \\
1.000\end{array}$ & $\begin{array}{l}0.43 I^{*} \\
0.909 \\
1.000\end{array}$ \\
\hline $\begin{array}{l}\text { Type of toilet facility } \\
\text { Flush toilet } \\
\text { Pit latrine/No facility (ref.) }\end{array}$ & & $\begin{array}{l}0.384^{*} \\
1.000\end{array}$ & $\begin{array}{l}0.333^{*} \\
1.000\end{array}$ & $\begin{array}{l}0.354 * \\
1.000\end{array}$ \\
\hline $\begin{array}{l}\text { Toilet facilities shared } \\
\text { No } \\
\text { Yes (ref.) }\end{array}$ & & $\begin{array}{l}1.393^{*} \\
1.000\end{array}$ & $\begin{array}{l}1.402 * \\
1.000\end{array}$ & $\begin{array}{l}1.369 * \\
1.000\end{array}$ \\
\hline $\begin{array}{l}\text { Type of flooring material } \\
\text { Natural/rudimentary } \\
\text { Finished (ref.) }\end{array}$ & & $\begin{array}{l}1.000 \\
0.619 *\end{array}$ & $\begin{array}{l}1.000 \\
0.649 *\end{array}$ & $\begin{array}{l}1.000 \\
0.806\end{array}$ \\
\hline $\begin{array}{l}\text { Type of cooking } \\
\text { Electricity/gas/kerosene } \\
\text { Firewood/charcoal (ref.) }\end{array}$ & & $\begin{array}{l}1.414 \\
1.000\end{array}$ & $\begin{array}{l}1.605 \\
1.000\end{array}$ & $\begin{array}{l}1.973 * \\
1.000\end{array}$ \\
\hline $\begin{array}{l}\text { Place for Hand washing } \\
\text { Indwelling yard } \\
\text { Nowhere/somewhere else } \\
\text { (ref.) }\end{array}$ & & $\begin{array}{l}\mathrm{I} .114 \\
\mathrm{I} .000\end{array}$ & $\begin{array}{l}0.984 \\
1.000\end{array}$ & $\begin{array}{l}0.986 \\
1.000\end{array}$ \\
\hline $\begin{array}{l}\text { Wash hand before prepari } \\
\text { last meal } \\
\text { No } \\
\text { Yes (ref.) }\end{array}$ & & $\begin{array}{l}0.729 \\
1.000\end{array}$ & $\begin{array}{l}0.649 \\
1.000\end{array}$ & $\begin{array}{l}0.671 \\
1.000\end{array}$ \\
\hline $\begin{array}{l}\text { Sex of child } \\
\text { Male } \\
\text { Female (ref.) }\end{array}$ & & & $\begin{array}{l}1.255 \\
1.000\end{array}$ & $\begin{array}{l}1.286 \\
1.000\end{array}$ \\
\hline $\begin{array}{l}\text { Type of birth } \\
\text { Single } \\
\text { Multiple (ref.) }\end{array}$ & & & $\begin{array}{l}0.247^{*} \\
1.000\end{array}$ & $\begin{array}{l}0.243^{*} \\
1.000\end{array}$ \\
\hline $\begin{array}{l}\text { Birth order } \\
\text { Second-born (ref.) } \\
\text { Third-born } \\
\text { Fourth-born and above }\end{array}$ & & & $\begin{array}{l}1.000 \\
0.842 \\
1.095\end{array}$ & $\begin{array}{l}1.000 \\
0.809 \\
0.988\end{array}$ \\
\hline
\end{tabular}




\begin{tabular}{lll} 
Age of mother at birth & & \\
I5-19 (ref.) & 1.000 & 1.000 \\
$20-24$ & $0.390^{*}$ & $0.393^{*}$ \\
$25-29$ & $0.430^{*}$ & $0.448^{*}$ \\
$30-34$ & 0.592 & 0.606 \\
$35-39$ & 0.681 & 0.682 \\
40 and above & 1.039 & 1.046 \\
Birth interval & & \\
Below 24 months (ref.) & 1.000 & 1.000 \\
$24-35$ months & $0.739^{*}$ & 0.749 \\
36 months and above & $0.402^{*}$ & $0.400^{*}$ \\
Maternal educational level & & \\
No education (ref.) & & 1.000 \\
Primary & & 1.100 \\
Secondary & & $0.575^{*}$ \\
Higher & & 0.831 \\
Type of Residence & & \\
Urban & & 1.036 \\
Rural (ref.) & & 1.000 \\
Work status & & \\
Not working (ref.) & & 1.000 \\
Working & & 1.139 \\
Wealth Index & & \\
Low (ref.) & & 1.000 \\
Middle & & 0.665 \\
High & & 0.688 \\
\hline Sourc: NDHS & &
\end{tabular}

Source: NDHS 2003 Secondary data analysis * $-p<0.05$

The mother's age has been found in various studies to be important determinants of child's health. Children born five years preceding the survey to mothers aged 20-29 have a significantly lower risk than those of age 15-19. Adolescent motherhood is reflected in women aged 15-19 while those of 2029 years are in their early and mid reproductive years. Although these two age groups grew up in a period of higher enrolment in formal education, higher participation in labour force and more campaign on maternal and child's health, the risk to under-five death is significantly higher among these age groups. As expected in fertility behaviour, the risk to childhood mortality among births to mothers aged 30 and above increases when compared to the reference category. Also, children whose preceding birth interval is two years and above have lower chance of death than those below two years.

The inclusion of socio-economic variables in model 4 shows that there is no significant difference in ethnic group membership and childhood mortality in Nigeria. This is very pertinent as this model includes all other variables. This implies that the disparities in childhood mortality observed among the ethnic groups in this study could be controlled if the household environment, demographic variables and socio-economic variables are relatively similar. The pattern of household environment and demographic variables on childhood mortality in Model 2 and 3 did not change after the inclusion of socio-eco- 
nomic variables in Model 4. However, this result reveals that while residence, wealth index and mothers' job status have no significant effects on childhood mortality, maternal education is significant. As expected, mothers with secondary education have lower chances of experiencing under-five death than those in the reference category (No education). High levels of maternal education have been associated with better understanding and appreciation for hygiene and child's health.

Overall, the household environmental variables affect the relative hazard of deaths among Nigerian ethnic groups in this study and there are significant mediating effects of demographic and socio-economic variables. All these variables tend to lower the disparities noticed in under-five deaths among Nigerian ethnic groups.

\section{Discussion and conclusion}

The pattern of childhood morbidity and mortality was examined among Nigerian ethnic groups. The findings in this study did not deviate from the theoretical supposition that least modernized groups are more likely to indulge in socio-cultural practices detrimental to under-five survival (Gyimah, 2002).. Responses on the incidence of diarrhea in the last two weeks preceding the survey show that children born to Yoruba women have the least episode. The high incidence of childhood diarrhea among the Hausa-Fulani, northern minorities and southern minorities' ethnic groups is alarming as dehydration from diarrhea has been identified as one of the causes of death among young children in Nigeria. The fact that the source of drinking water is a correlate of childhood diarrhea as reported in literatures is buttressed in this study (Jinadu et al., 1991; Kwasi and Markku, 2005). The source of drinking water for these two ethnic groups has shown that drinking water is a major determinant to the incidence of childhood diarrhea; the groups with improved source of drinking water have the least incidence of childhood diarrhea.

Incidence of cough or short rapid breath within two weeks preceding the survey is highest among SM group and lowest among the Yoruba. Although, acute respiratory infection is expected to be significant among the ethnic groups where biomass fuel (firewood, charcoal, straw) is used for cooking, the incidence is surprisingly similar in all ethnic groups irrespective of the type of cooking fuel. This can be attributed to other factors found in other studies such as environmental pollution from emission of carbons in the more industrialised southern area of Nigeria (Mishra and Retherford, 2007). World Health Statistics 2009 estimate that fever is common childhood morbidity in developing countries, especially SubSaharan Africa where about 15 in 1000 live-birth die from malaria before the age of five. The finding in this study is consistent with the report. It is quite alarming that within two weeks preceding the survey, about one third of the analytical sampled children under-five reported incidence of fever among the Hausa-Fulani, Northern and Southern minorities' ethnic groups. One the factors responsible for this high incidence is overall low usage of mosquito net despite awareness on prevention of malaria through the use of mosquito 
nets. These malaria-carrying mosquitoes are responsible for the majority of malaria deaths in Nigeria, and the groups most vulnerable are children under five years of age and pregnant women. Although the 2003 NDHS survey was carried out during the rainy season, a period of prevalence of malaria-carrying mosquitoes when mosquito nets were most likely to be used, the usage is low and the incidence of fever is high (NPC, 2004)

As found in the literature, survival chances of infants are generally lower than children above one year old (Zenger, 1992; WHO, 2009). Deaths of infants, especially during the neonatal period, are higher than after one year. The findings reveal that among all the ethnic groups, infants generally have lower chances of survival than children above one year old, with children born to Hausa-Fulani mothers having relative high risk to infant mortality. There is a wide margin when all other ethnic groups are compared with the Yoruba on infant mortality. Furthermore, children within the age 13-59 months in the ethnic groups in the southern part of Nigeria can, on the average, survive child mortality than those in the Northern part. Hausa-Fulani group, the least educated group, has the highest number of deaths of children under-five among the ethnic groups in the country. The geographic location and cultural similarity of Northern minorities and Hausa-Fulani are evident in the high incidence of childhood mortality for the two ethnic groups. However, the relative hazard of death is significantly lower among children born to Yoruba mothers, Southern minorities and Igbo for under-five mortality. This is consist- ent with findings in Cameroon where high under-five mortality among the Fulbe-Fulani group is explained by lack of formal education (Kuarte Defo, 1996).

The findings from qualitative data as also observed in other studies show that it is believed that the cause of death is illness, which is inevitable among children, especially those under five years of age (Ogunjuyigbe, 2004; Onyeabochukwu, 2007). There are some differences in the perceived causes of childhood morbidity among the Nigerian ethnic groups. Contaminated/dirty water and teething are generally perceived in all the ethnic groups as causes of diarrhea among under-five children. The Igbo and Yoruba mothers mentioned improper care of the feeding bottle as an additional cause of childhood diarrhea. Measles is seen as normal for Tiv children while the remaining ethnic group attributed incidence of measles to heat. Exposure to cold, smoke from firewood and bare floor are mentioned as causes of cough and catarrh among the children underfive in Nigeria. Though the pattern of perceived causes of childhood morbidity varies slightly, a higher proportion of mothers, irrespective of residence, mentioned modern treatment/curative measures in all the ethnic groups for this study. However, some children are believed will still die irrespective of treatment given when they are sick because of their parents' refusal to acknowledge a particular taboo or beliefs that the community adheres to.

The ethnic disparities in childhood morbidity and mortality are clearly demonstrated in this study. The chance of survival for children born to mothers 
whose ethnic groups from the southern part of Nigerian are higher than the northern part. Likewise, there are disparities in the risk of childhood mortality based on the type of health hazards the child is exposed to within the household environment. This study also observes that children are highly valued among all ethnic groups and traditional methods of childcare have been gradually modified through the incorporation of safe method of childcare. There are also significant mediating effects of household environment, demographic and socio-economic variables on underfive mortality in Nigeria. The values placed on children among all ethnic groups were reflected in different socio-cultural beliefs and practices with significant influence of urban residence and education of mothers.

\section{Acknowledgements}

The Council for the Development of Social Science Research in Africa (CODESRIA) for sponsoring the fieldwork for this study under the award of Small Grant for Thesis Writing 2005. The African Population and Health Research Center (APHRC), the International Development Research Centre (IDRC), and the Ford Foundation for sponsoring the completion stage of the research through the African Doctoral Dissertation Research Fellowship 2008.

\section{References}

Ajala, A. S. 2002. Cultural practices relating to breastfeeding and their implications for maternal and child healthcare in a rural community of Osun State, Nigeria. West African Journal of Archaeology 32 (I): $109-130$

Alabi, E.M. 1990. Cultural practices in
Nigeria. Newsletter of Inter-African Committee on traditional practices that affect health of women and children.

Balk, D., Pullum, T., Storeygard, A., Greenwell, F. and Neuman, M. 2004. A spatial analysis of childhood mortality in West Africa. Population, Space and Place 10:175-216

Berk, L.E. 2000. Child Development ( $5^{\text {th }}$ ed.). Boston: Allyn and Bacon. 23-38

Brofenbrenner, U. 1979. The ecology of human development: Experiments by nature and design. Cambridge, MA: Harvard University Press.

Brockerhoff, M. and Hewett, P. 1998. Ethnicity and Child Mortality in SubSaharan Africa Population Council Working Papers No. 107

Brockerhoff, M. and Hewett, P. 2000. Inequality of child mortality among ethnic groups in Sub-Saharan Africa. Bulletin of World Health Organisation 78: 30-4I

Gaisie, S. 1990. Culture and health in SubSaharan Africa, in John Caldwell et al., (eds.), What we know about health transition: The cultural, social, and behavioural determinants of health: The Proceedings of an International Workshop, Canberra, May 1989, Vol. II, pp. 609627. Canberra: Health Transition Centre, Australian National University.

Gyimah, S.O. 2002. Ethnicity and infant mortality in Sub-Saharan Africa: The case of Ghana. Population Studies Centre Discussion Paper, Number 02-10. The University of Western Ontario, London, Ontario, Canada

lyun, B.F. 2000. Environmental factors, situation of women and child mortality in south western Nigeria. Social Science and Medicine, $5 \mathrm{I}$ ( I 0): I 473 - I 489.

Jinadu, M.K., Olusi, S.O., Agun, J.I., and Fabiyi A.K., 1991. Childhood diarrhea in rural Nigeria: Studies on prevalence, mortality and socio-environmental factors. Journal of Diarrhea Diseases Research 9(4): 323-327. 
Kuate Defo B, 1996. Areal and socioeconomic differentials in infant and child mortality in Cameroon. Social Science and Medicine 42 (3): 399-420

Kwasi, O.B. and Markku, K. 2005. Childhood diarrhea morbidity in the Accra metropolitan area, Ghana: Socioeconomic environmental and behavioural risk determinants. The Journal of Health and Population in Developing Countries /URL:http/ jhpdc.unc.edu/

Louse Ross, S.N.M., 198I. Weaning Practices. Journal of Nurse-Midwifery. 26(I): 9-14.

Macassa, G., Ghilagaber G., Bernhardt, E., and Burstrom, B. 2006. Inequalities in under-five mortality in Mozambique: differentials by region of residence and ethnic affiliation of the mother. East African Medical Journal 83: 259-266

Mishra, V. and Retherford, R. D. 2007. Does biofuel smoke contribute to anaemia and stunting in early childhood? International Journal of Epidemiology Vol.36 ppl I7-I 29

National Population Commission (NPC) (Nigeria) and ORC Macro 2004. Demographic and Health Survey, 2003, Calverton, Maryland: National Population Commission and ORC Macro.

Ogunjuyigbe, P.O. 2004. Under-Five Mortality in Nigeria: Perception and Attitudes of the Yorubas towards the existence of "Abiku" Demographic Research II(2): 44-54

Onofiok, N.O. and Nnanyelugo D.O. 1988. Weaning foods in West Africa: Nutritional problems and possible solutions. Food and Nutrition Bulletin. 19:I Retrieved online on January 2010 from http://www.unu.edu/unupress/food/ VI9le/ch06.htm

Onyeabochukwu, D. A. 2007. Cultural practices and health: The Nigerian experience. Meddika- Journal of the University of Nigeria Medical Student.
Retrieved online on January 20 I0. http:// I990unecmedclass.com/ culturalpractices.htm

Otite, O. 1990. Ethnic pluralism and ethnicity in Nigeria. Shaneson Limited. Nigeria.

Oyekanmi, F.A.D. 1998. Socio-cultural relations in the Nigerian family: implications for AIDS in Nigeria. CODESRIA Publications. Retrieved online on January 2010. http:// www.codesria.org/Links/Publications/aids/ oyekanmi.pdf

Policy Project/Nigeria, 2002: Child survival in Nigeria: Situation response and prospect: Key issue. Abuja Policy Project.

Rutstein, S.O. 2000. Factors associated with trends in infant and child mortality in developing countries during the 1990s. Bulletin of the World Health Organisation 78: I256- 1270.

Schaefer, R., Smith, E. and Grekul, J. 2009. Sociology. McGraw-Hill Ryerson. Canada.

Teerawichitchainan, B. and Phillips, J. F. 2008. Ethnic differentials in parental health seeking for childhood illness in Vietnam, Social Science \& Medicine. 66(5): III8-II30.

Venkatacharya K. 1991. Kenya Case Studies: Child Mortality in Developing Countries: Socioeconomic differentials, trends and implication. United Nation, New York

Wahab, B. 2004. African traditional religions, environmental, health and sanitations in rural communities. The Environscope Vol.I No.I ppl-9

World Health Organisation 2009. World Health Statistics 2009. Geneva: The World Health Organisation

Yinger, J.M. 1985. Ethnicity. Annual Review of Sociology. II: $151-180$

Zenger, E. 1992. Siblings' neonatal morality risks and birth spacing in Bangladesh. Demography.30:477 - 488 